\title{
PENGARUH MEKANISME CORPORATE GOVERNANCE DAN STRUKTUR KEPEMILIKAN PUBLIK TERHADAP LUAS PENGUNGKAPAN ENTERPRISE RISK MANAGEMENT
}

\author{
Barbara Gunawan* \\ Fakultas Ekonomi dan Bisnis, Universitas Muhammadiyah Yogyakarta \\ e-mail: barbaragunawan@yahoo.co.id
}

\begin{abstract}
This research aims to examine the effect of corporate governance mechanisms and the structure of public ownership on the broad disclosure of enterprise risk management in manufacturing companies in Indonesia and Malaysia. The sample in this study were manufacturing companies listed on the Indonesia Stock Exchange and Malaysia Stock Exchange in the period 2015 - 2017. This study uses secondary data. Data collection techniques used purposive sampling method and obtained 183 samples in Indonesia and 180 samples in Malaysia. This research use SPSS version 15.0 as data analysis tool. The results of the analysis obtained indicate that the Independent Commissioner, the reputation of the auditor, and the size of the company have a positive effect on the broad disclosure of enterprise risk management. While the number of members of the board of commissioners and the structure of public ownership negatively affected the broad adoption of enterprise risk management in Indonesian manufacturing companies. the results of the analysis of Independent Commissioners, the number of members of the board of commissioners, and the reputation of the auditor have a positive effect on the broad disclosure of enterprise risk management. While the size of the company and the structure of public ownership negatively affect the Broad Disclosure of Enterprise Risk Management in manufacturing companies in Malaysia.

Keywords: Structure of Corporate Governance, Public Ownership Structure, Enterprise Risk Management

Abstrak

Penelitian ini bertujuan untuk menguji pengaruh mekanisme corporate governance dan struktur kepemilikan publik terhadap luas pengungkapan Enterprise Risk Management pada perusahaan manufaktur di Indonesia dan Malaysia. Sampel pada penelitian ini yaitu perusahaan manufaktur yang terdaftar di Bursa Efek Indonesia (IDX) dan Bursa Efek Malaysia (BM) periode 2015 - 2017. Penelitian ini menggunakan data sekunder. Teknik pengumpulan data menggunakan metode purposive sampling dan memperoleh 183 sampel di Indonesia dan 180 sampel di Malaysia. Alat analisis pada penelitian ini adalah SPSS versi 15.0. Hasil analisis yang diperoleh menunjukkan bahwa komisaris independen, reputasi auditor, dan ukuran perusahaan berpengaruh positif terhadap luas pengungkapan Enterprise Risk Management. Sedangkan Jumlah anggota dewan komisaris dan struktur kepemilikan publik berpengaruh negatif terhadap luas pengungapan Enterprise Risk Management di perusahaan manufaktur Indonesia. hasil analisis komisaris independen, jumlah anggota dewan komisaris, dan reputasi auditor berpengaruh positif terhadap luas pengungkapan Enterprise Risk Management. Sedangkan ukuran perusahaan dan struktur kepemilikan publik berpengaruh negatif terhadap luas pengungkapan Enterprise Risk Management perusahaan manufaktur di Malaysia.
\end{abstract}

Kata Kunci : Struktur Corporate Governance, Struktur Kepemilikan Publik, Enterprise Risk Management

\section{I, PENDAHULUAN}

Pada tahun 2017 muncul isu fraud akuntansi di British Telecom. Sebagaimana skandal akuntansi lainnya, kasus fraud tersebut berdampak negatif kepada akutan publiknya. Price Waterhouse Coopers (PwC) merupakan kantor akuntan publik di dunia dan termasuk dalam the bigfour juga terkena dampak dalam isu fraud yang terjadi. Modus yang terjadi dalam fraud yaitu membesarkan penghasilan perusahaan melalui perpanjangan kontrak palsu dan invoice-nya serta transaksi palsu pada vendor.

Dampak lain fraud akuntansi penggelembungan laba ini menyebabkan Britis Telecom harus menurunkan GBP 530 juta dan mendorong proyeksi arus kas sebesar GBP 500 juta untuk membayar hutang yang tidak dilaporkan. British Telecom telah rugi membayar pajak penghasilan atas laba yang tidak 
sebenarnya. Skandal akuntansi ini juga menyebabkan kerugian pada pemegang saham dan investor dimana harga saham British Telecom anjlok ketika British Telecom mengumumkan koreksi pendapatan sebesar GBP 530 juta di bulan Januari. Fraud atau kecurangan tidak hanya terjadi di perusahaan kecil saja, melainkan banyak terjadi di perusahaan besar yang maju korporasi ternama dan negara berkembang. Ini artinya fraud dianggap sebagai ancaman atau risiko yang terdapat di setiap organisasi.

Indonesia salah satu negara ASEAN yang menarik banyak pelaku usaha asing untuk membangun usahanya dikarenakan potensi pasarnya lebih besar. Negara lain contohnya Malaysia merupakan negara yang memiliki perekonom

Ketidakpastian adalah suatu hal yang tidak bisa dihindari dalam dunia bisnis. Kegiatan investasi juga merupakan kegiatan di dalam bisnis yang membutuhkan informasi yang relevan dan satu kegiatan bisnis yang mengandung risiko dan ketidakpastian. Situasi ketidakpastian lingkungan dan persaingan kompetitif, perusahaan menghadapi berbagai risiko dalam mempertahankan dan meningkatkan kinerja mereka sendiri. Untuk meminimalisir kerugian yang disebabkan oleh risiko, perusahaan harus dikelola dengan baik dan bijak dalam menggunakan manajemen risiko. Kegagalan dalam manajemen risiko akan menyebabkan kerugian dalam perusahaan, secara langsung maupun tidak langsung, sebagai konsekuensi dari kegiatan bisnis yang menimbulkan risiko (Halim et al., 2017)

ian yang baik di bidang industri. Pada era ekonomi global saat ini terjadi persaingan bisnis yang cukup ketat, banyak perusahaan dihadapkan pada kondisi yang lebih transparan dalam pengungkapan informasi laporan keuangan yang terdapat di perusahaan, terlebih pada perusahaan go public di pasar modal. Dengan menerapkan sistem go public perusahaan bisa memperbaiki citra dengan mengedepankan tata kelola perusahaan dengan sistem transparan atau Good Corporate Governance (GCG).

Risiko juga berkaitan dengan keberhasilan dan kegagalan, sistem manajemen risiko yang baik merupakan suatu kekuatan bagi perusahaan dalam membantu pencapaian tujuan bisnis perusahaan dan peningkatan kualitas pengungkapan dan pelaporan keuangan sebagai usaha perlindungan reputasi perusahaan (Ardiansyah \& Adnan, 2014).
Pengungkapan informasi yang transparan tersebut membuat beberapa pihak yang berkepentingan contohnya investor, kreditor, maupun pengguna informasi lainnya dapat terbantu dapat pengambilan keputusan dan kesiapan dalam menghadapi era perekonomian yang semakin berkembang saat ini. Salah satu pemegang saham dalam sebuah perusahaan yaitu publik atau masyarakat pada umumnya yang memiliki pengaruh cukup besar terhadap perusahaan.

Struktur kepemilikan publik yaitu suatu perusahaan yang menyediakan pengungkapan informasi yang memadai sebagai bentuk transparansi dan akuntabilitas (Fathimiyah et al., 2012). Hal tersebut disebabkan oleh semakin besar saham yang dimiliki masyarakat maka pihak yang membutuhkan transparansi mengenai laporan keuangan semakin banyak. Sebagai bentuk pertanggungjawaban terhadap investor perusahaan akan dituntut untuk memberikan laporan informasi secara terbuka dan secara transparan. Oleh sebab itu laporan keuangan yang dikelola sendiri menjadikan banyak batasan dan tidak bisa dimanipulasi (Kanhai \& L, 2014).

Perkembangan teknologi di ASEAN saat ini mengalami persaingan bisnis di berbagai perusahaan. Dengan adanya persaingan bisnis yang sangat ketat ini, membuat setiap perusahaan berlomba-lomba untuk memberi nilai tambah kepada stakeholder, hal ini suatu pencapaian perusahaan. Dengan pencapaian tersebut perusahaan akan dihadapkan dengan ketidakpastian.

Pengungkapan Enterprise Risk Management (ERM) salah satu cara perusahaan go publik yang dapat membantu publik untuk percaya pada keakuratan pelaporan keuangan dan meminimalisir pihak yang tidak bertanggungjawab dalam penyalahgunaan laporan keuangan (Handayani \& Yanto, 2013). Pada dasarnya ERM menuntut adanya sistem transparan dan keterbukaan dalam pelaporan keuangan yang mengacu pada manajemen risiko. Selain itu pengungkapan ERM sudah diterapkan sebagian di negara Asia Tenggara. Contoh dari beberapa negara yang sudah menerapkan ERM dalam mengelola risiko adalah Indonesia dan Malaysia. Keduanya merupakan sebagian dari beberapa negara yang merupakan bagian dari ASEAN. Dengan menerapkan ERM dengan baik, maka manajemen risiko dapat membuat langkah untuk kesuksesan di masa depan perusahaannya. Oleh karena itu mekanisme corporate governance seharusnya dapat dilihat dari tingkat transparansi dalam menyampaikan segala bentuk laporan. Laporan untuk pihak internal 
maupun eksternal perusahaan.

Perkembangan ERM, khususnya di negara Indonesia dan Malaysia sudah mulai berjalan dan berkembang dengan baik. Sebagian contoh berkembangan ERM di Indonesia pada tahun 2016, PT Pertamina EP sebagai anak buah dari PT. Pertamina (Persero) dan kontraktor kontrak kerja sama di bawah naungan SKKMigas menjuarai ajang Asean Risk Management 2016 yang diikuti oleh 23 perusahaan di kawasan ASEAN. Ajang Asean Risk Management 2016 yang diadakan oleh Enterprise Risk Management Academy melakukan penilaian kepada perusahaan di wilayah ASEAN terkait bagaimana pengelolaan faktor risiko di dalam perusahaan

Selain itu di Indonesia, setelah dikeluarkannya Peraturan Bank Indonesia No8/4/PBI/2006 yang membahas tentang penerapan GCG bagi Bank Umum dengan pembentukan Komite Pemantauan Risiko. Pembentukan Komite Pemantauan Risiko merupakan salah satu persyaratan yang harus dilengkapi oleh bank umum. Bagi bank yang belum membentuk komite pemantauan risiko akan dihadapkan dengan sanksi dari Bank Indonesia. The Committee of Sponsoring of the Tread way Commission (COSO) mulai memperkenalkan ERM dan dipublikasi sejak tahun 2004. COSO mengemukakan bahwa ERM mampu memberikan konsep dan prinsip utama, pedoman dan arahan yang jelas. Bahkan lebih lanjut diharapkan mampu diterima secara meluas oleh berbagai perusahaan dan organisasi lainnya, stakeholder dan berbagai pihak yang berkepentingan. ERM juga sudah berkembang secara baik di berbagai negara di ASEAN, selain Indonesia negara Malaysia sudah menerapkan sistem ERM dalam sistem operasional di dalam perusahaannya

\section{TINJAUAN PUSTAKA}

\section{Enterprise Risk Management}

Enterprise Risk Management merupakan pendekatan manajemen risiko yang mempertimbangkan risiko dalam hal strategi bisnis dan mengelola hal tersebut dengan portofolio yang berfokus pada risiko kritis, pertanggung jawaban risiko yang ditetapkan, dan risiko yang kuat pemantauannya. Berdasarkan ERM framework yang dikeluarkan COSO 2004, dalam 108 item mengenai pengungkapan ERM terdapat 8 dimensi yang memengaruhi ERM yaitu Lingkungan internal;
Penempatan tujuan; Identifikasi kejadian; Penilaian risiko; Respond atas risiko; Kegiatan pengawasan; Informasi dan komunikasi; dan Pemantauan (Meizaroh \& Lucyanda, 2011).

Perhitungan item-item yang digunakan menggunakan pendekatan diktomi. Pendekatan dikotomi adalah item ERM yang diungkapkan diberi nilai 1, dan perhitungan tidak diungkapkan diberi nilai 0 . Setiap item akan dijumlahkan guna memeroleh keseluruhan indeks ERM masing-masing perusahaan. Pada penelitian ini cara menghitung indeks pengungkapan ERM dinyatakan sebagai berikut:

$E R M=\frac{\text { Jumlah Item yang Diungkapkan }}{108}$

\section{Komisaris independen}

Variabel komisaris independen dengan diproksikan dengan komisaris independen. Proporsi komisaris independen mencerminkan kadar objektivitas dan independensi dari keseluruhan dewan komisaris dalam aktivitas pengambilan keputusan (Wulandari, 2018). Dalam penelitian ini komisaris independensi dirumuskan sebagai berikut:

$K I=\frac{\text { jumlah dalam anggota komisaris independen }}{\text { jumlah total dalam anggota dewan komisaris }}$

\section{Ukuran dewan komisaris}

Dewan komisaris merupakan suatu mekanisme yang bertugas untuk mengawasi dan memberikan arahan pada pengelola perusahaan. Ukuran dewan komisaris diukur dengan menjumlahkan total anggota dewan komisaris yang terdapat di perusahaan.

\section{Reputasi auditor}

Reputasi auditor menunjukkan bagaimana perusahaan dengan bijak dan baik dalam menggunakan KAP sebagai auditor eksternal nya. Reputasi auditor dapat diukur menggunakan variabel dummy apabila perusahaan menggunakan KAP big four diberi nilai 1 dan jika tidak menggunakan diberi nilai 0 .

\section{Ukuran perusahaan}

Ukuran perusahaan dapat digambarkan dengan besar kecilnya perusahaan tersebut. Ukuran perusahaan banyaknya jumlah aset yang dimiliki oleh suatu perusahaan. Penelitian ini mengukur total aset 
yang dimiliki perusahaan (Ardiansyah \& Adnan, 2014). Rumus dalam menghitung ukuran perusahaan sebagai berikut:

Ukuran Perusahaan $=L N$ (total aset)

\section{Struktur kepemilikan publik}

Struktur kepemilikan publik merupakan jumlah komposisi yang setara yang berasal dari pihak internal maupun eksternal yang bersama dalam memajukan perusahaan (Ardiansyah \& Adnan, 2014). Struktur internal dimaksudkan adalah manajerial perusahaan, sedangkan struktur eksternal adalah kepemilikan investor, masyarakat (publik), dan sebagainya. Oleh sebab itu perusahaan yang tingkat kepemilikan publiknya lebih tinggi akan lebih cenderung tepat waktu dalam menyampaikan laporan keuangannya. Rumus yang dipergunakan dalam menjumlahkan struktur kepemilikan publik sebagai berikut:

$$
K K=\frac{\text { saham yang dimiliki oleh publik }}{\text { total saham }}
$$

\section{Komisaris Independen dan Luas Pengungkapan ERM}

Dewan komisaris salah satu yang memegang peranan terpenting bagi perusahaan, terutama dalam pelaksanaan Good Corporate Governance. Jumlah anggota dewan yang lebih besar akan memberikan manfaat untuk bertugas mengawasi dewan direksi dan membentuk komite dengan keterampilan yang diperlukan. Dewan komisaris dapat membentuk koordinasi yang dapat mengurangi risiko (Ardiansyah \& Adnan, 2014) .

Tujuan dewan komisaris independen yaitu untuk mendorong suatu keadaan yang lebih baik dan menaruh keseimbangan diantara para kepentingan perusahaan dengan kepentingan stakeholder. (Handayani \& Yanto, 2013) menemukan bahwa komisaris independen berpengaruh signifikan terhadap luas pengungkapan ERM. Hasil penelitian berbeda dengan penelitian yang dilakukan (Agista et al., 2017) menunjukkan bahwa komisaris independen tidak memiliki pengaruh terhadap luas pengungkapan ERM. Berdasarkan alasan dan hasil penelitian tersebut, maka hipotesis yang diajukan:

$\mathrm{H}_{1 \mathrm{a}}$ : Komisaris Independen berpengaruh positif terhadap luas pengungkapan ERM di Indonesia.

$\mathrm{H}_{1 b}$ : Komisaris Independen berpengaruh positif terhadap luas pengungkapan ERM di Malaysia.

\section{Jumlah Anggota Dewan Komisaris dan Luas Pengungkapan ERM}

Dewan komisaris mempunyai tugas untuk melakukan monitoring dan mengevaluasi seluruh pelaksanaan aturan perusahaan yang dibuat oleh perusahaan serta memberikan nasihat kepada dewan direksi. Dewan komisaris perusahaan minimal berjumlah dua orang. Pemberhentian maupun pengangkatan jabatan dewan komisaris dilakukan melalui rapat umum pemegang saham, dan tidak boleh diputuskan secara sepihak. Oleh sebab itu, dapat memudahkan dewan komisaris untuk bekerja sama dengan komite manajemen risiko yang telah dibuat.

Semakin banyak jumlah anggota dewan komisaris maka dapat memengaruhi manajer dalam menjalankan tugasnya dengan baik (Meizaroh \& Lucyanda, 2011). Sejalan dengan penelitian yang dilakukan (Ardiansyah \& Adnan, 2014) menemukan bahwa jumlah anggota komisaris memiliki pengaruh terhadap luas pengungkapan ERM. Berbeda dengan penelitian yang dilakukan (Dzakawali et al., 2017) menunjukkan bahwa jumlah anggota dewan tidak berpengaruh terhadap luas pengungkapan ERM. Berdasarkan penjelasan tersebut, maka hipotesis yang diajukan adalah:

$\mathrm{H}_{2 \mathrm{a}}$ : Jumlah Anggota Dewan Komisaris berpengaruh positif terhadap luas pengungkapan ERM di Indonesia.

$\mathrm{H}_{2 \mathrm{~b}}$ :Jumlah Anggota Dewan Komisaris berpengaruh positif pengungkapan ERM di Malaysia.

\section{Reputasi Auditor dan Luas Pengungkapan ERM}

Reputasi auditor merupakan istilah auditor yang memiliki nama baik, kepercayaan publik, serta memiliki prestasi atas jasa yang telah diberikan. Big four yang merupakan proksi dari reputasi auditor dikarenakan Big four dapat melihat dan memiliki kekuatan dalam melakukan analisis manajemen agar bisa memberikan kualitas penilaian dan pengawasan risiko dalam sebuah perusahaan (Ardiansyah \& Adnan, 2014) . Kantor Akuntan Publik (KAP) yang tergolong dalam Big four adalah KAP yang mempunyai reputasi dengan kualitas audit yang terpercaya. (Meizaroh \& Lucyanda, 2011) 
menjelaskan jika Big four dapat memberikan panduan akan praktik Good Corporate Governance dan dapat membantu internal auditor dalam meningkatkan efektifitas. (Handayani \& Yanto, 2013) menemukan bahwa Big four memiliki pengaruh positif terhadap ERM. Sehingga hipotesis yang diajukan adalah:

$\mathrm{H}_{3 \mathrm{a}}$ : Reputasi Auditor berpengaruh positif terhadap luas pengungkapan ERM di Indonesia.

$\mathrm{H}_{3 b}$ : Reputasi Auditor berpengaruh positif terhadap luas pengungkapan ERM di Malaysia.

\section{Ukuran Perusahaan dan Luas Pengungkapan ERM}

Besar kecilnya perusahaan menunjukkan adanya ukuran di dalam perusahaan tersebut. (Firdaus, Haris, 2014) menjelaskan ukuran perusahaan dibagi menjadi 3 kategori yaitu perusahaan besar, perusahaan menengah, dan perusahaan kecil. Pada dasarnya semakin besar perusahaan maka semakin besar risiko yang akan dihadapi ke depannya. Perusahaan yang sudah berkembang biasanya menerapkan konsep GCG yang lebih bagus dibandingkan dengan perusahaan yang lain (Ardiansyah \& Adnan, 2014).

Perusahaan yang sudah berkembang atau perusahaan yang cukup besar akan mendapatkan dorongan yang kuat dalam mengungkapkan pelaporan keuangan, hal ini sejalan dengan penelitian (Handayani \& Yanto, 2013) bahwa perusahaan dengan ukuran besar memiliki kegiatan yang lebih terstruktur, oleh sebab itu dapat menyebabkan pengungkapan informasi yang lebih baik untuk menunjukkan pertanggungjawaban perusahaan kepada publik. Sehingga hipotesis yang diajukan dalam penelitian ini adalah:

$\mathrm{H}_{4 \mathrm{a}}$ : Ukuran perusahaan berpengaruh positif terhadap luas pengungkapan ERM di Indonesia.

$\mathrm{H}_{4 \mathrm{~b}}$ : Ukuran perusahaan berpengaruh positif terhadap luas pengungkapan ERM di Malaysia.

\section{Struktur Kepemilikan Publik dan Luas Pengungkapan ERM}

Struktur kepemilikan dapat digolongkan menjadi dua bagian yaitu kepemilikan eksternal dan kepemilikan internal atau kepemilikan manajerial (Ardiansyah \& Adnan, 2014). Apabila pihak eksternal lebih banyak memegang saham maka perusahaan akan dituntut untuk memberikan pengungkapan laporan yang luas dan transparan sebagai bentuk pertanggungjawaban kepada investor (Prayoga \& Almilia, 2013). Sementara menurut (Handayani \& Yanto, 2013) kepemilikan manajerial dan kepemilikan publik sendiri termasuk dalam mekanisme dari corporate governance yang paling berpengaruh dalam meminimalkan masalah dalam keagenan. Sehingga hipotesis yang diajukan dalam penelitian adalah:

$\mathrm{H}_{5 \mathrm{a}}$ :Struktur kepemilikan berpengaruh positif terhadap luas pengungkapan ERM di Indonesia.

$\mathrm{H}_{5 \mathrm{~b}}$ :Struktur kepemilikan berpengaruh positif terhadap luas pengungkapan ERM di Malaysia.

\section{METODE}

Objek pada penelitian ini adalah seluruh perusahaan manufaktur yang terdaftar di Bursa Efek Indonesia (IDX) dan Bursa Malaysia (BM) pada tahun 2015 - 2017. Periode tersebut dipilih guna untuk menggambarkan kondisi terbaru saat ini pada suatu perusahaan. Alasan peneliti menggunakan perusahaan manufaktur dikarenakan kategori tersebut termasuk di dalam perusahaan yang memperkuat perekonomian di negara berkembang seperti Indonesia dan Malaysia. Penelitian ini menggunakan data sekunder yang diambil dari annual report semua perusahaan manufaktur yang terdaftar di Bursa Efek Indonesia dan Bursa Malaysia. Teknik pengambilan sampel pada penelitian ini menggunakan metode purposive sampling yaitu sampel yang diambil berdasarkan informasi yang ada sesuai dengan kriteria 
yang ditentukan

Kriteria yang digunakan dalam penentuan sampel pada penelitian ini adalah:

1. Perusahaan manufaktur yang terdaftar di Bursa Efek Indonesia dan Bursa Malaysia yang mempublikasi laporan keuangan dan annual report secara berturut-turut pada periode 20152017.

2. Perusahaan manufaktur yang telah mengungkapkan manajemen resiko dalam laporan tahunan secara berkala selama periode penelitian.

3. Perusahaan manufaktur yang memiliki data yang dibutuhkan selama periode penelitian yaitu 20152017.

\section{Metode Analisis}

Diawali dengan Pengujian asumsi klasik yang terdiri dari Uji Normalitas, Uji Multikolineritas, uji autokorelasi, dan Uji Heterokedasitas.

Uji hipotesis pada penelitian ini menggunakan regresi berganda (Multiple Regression), dikarenakan variabel 26ndependent dalam penelitian ini lebih dari satu variabel. Persamaan regresinya dirumuskan sebagai berikut:

$$
\begin{gathered}
\mathrm{ERM}= \\
\beta 4 \mathrm{UK} \_\mathrm{KE}+\beta 5 \mathrm{KEP}+\mathrm{KBLK}+\mathrm{e}
\end{gathered}
$$

Dimana:

$\begin{array}{ll}\text { ERM } & : \text { Enterprise Risk Management } \\ \alpha & : \text { Konstanta } \\ \beta 1-\beta 5 & : \text { Koefisien variabel } \\ \text { KI } & : \text { Komisaris Independen } \\ \text { UKR_DWN } & : \text { Ukuran Dewan Komisaris } \\ \text { RE_AU: Reputasi Auditor } \\ \begin{array}{ll}\text { UK_PE: Ukuran Perusahaan } \\ \text { KEP_PBLK } & : \text { Struktur Kepemilikan Publik } \\ \text { e } & : \text { Error Term }\end{array}\end{array}$

\section{HASIL DAN PEMBAHASAN}

Objek yang digunakan dalam penelitian ini yaitu seluruh perusahaan manufaktur yang terdaftar di Bursa Efek Indonesia (BEI) dan Bursa Malaysia (BM) dengan periode penelitian tahun 2015 sampai dengan 2017. Data yang digunakan merupakan data sekunder, yaitu laporan keuangan tahunan perusahaan manufaktur yang terdaftar di Bursa Efek Indonesia (BEI) dan Bursa Malaysia (BM). Pengambilan sampel dilakukan dengan menggunakan metode purposive sampling. Adapun prosedur pemilihan sampel disajikan dalam Tabel 1. Hasil uji statistik deskriptif tampak pada Tabel 2. Hasil uji asumsi klasik berupa uji normalitas, uji autokorelasi, uji multikolinearitas, dan uji heteroskedastisitas tersaji di Tabel 3 sampai Tabel 10.

Tabel 1

\begin{tabular}{|c|c|c|c|}
\hline No & Keterangan & Indonesia & Malaysia \\
\hline 1 & $\begin{array}{l}\text { Perusahaan } \\
\text { manufaktur yang } \\
\text { terdaftar di BEI } \\
\text { dan menerbitkan } \\
\text { annual report } \\
\text { tahun 2015-2017 }\end{array}$ & 7 perusahaan & 0 perusahaan \\
\hline 2 & $\begin{array}{l}\text { Perusahaan yang } \\
\text { tidak } \\
\text { mengungkapkan } \\
\text { ERM dan GCG }\end{array}$ & ¡ perusahaan) & I perusahaan) \\
\hline 3 & $\begin{array}{l}\text { Perusahaan yang } \\
\text { tidak } \\
\text { mengungkapkan } \\
\text { ERM dan GCG }\end{array}$ & I perusahaan) & ) perusahaan) \\
\hline 4 & $\begin{array}{l}\text { Total } \\
\text { perusahaan yang } \\
\text { dijadikan sampel }\end{array}$ & I perusahaan & ) perusahaan \\
\hline \multicolumn{2}{|c|}{ Jumlah data } & 3 perusahaan & 0 perusahaan \\
\hline
\end{tabular}

Prosedur Pemilihan Sampel di Indonesia dan Malaysia

(Sumber : Data diolah)

\section{Analisis Statistik Deskriptif}

Statistik deskriptif pada penelitian ini menyajikan jumlah pengamatan, nilai minimum, nilai maksimum, nilai rata-rata (mean), dan standar deviasi dari variabel-variabel yang digunakan dalam penelitian. Adapun hasil statistik deskriptif dari variabel penelitian disajikan pada Tabel 2. 
Tabel 2

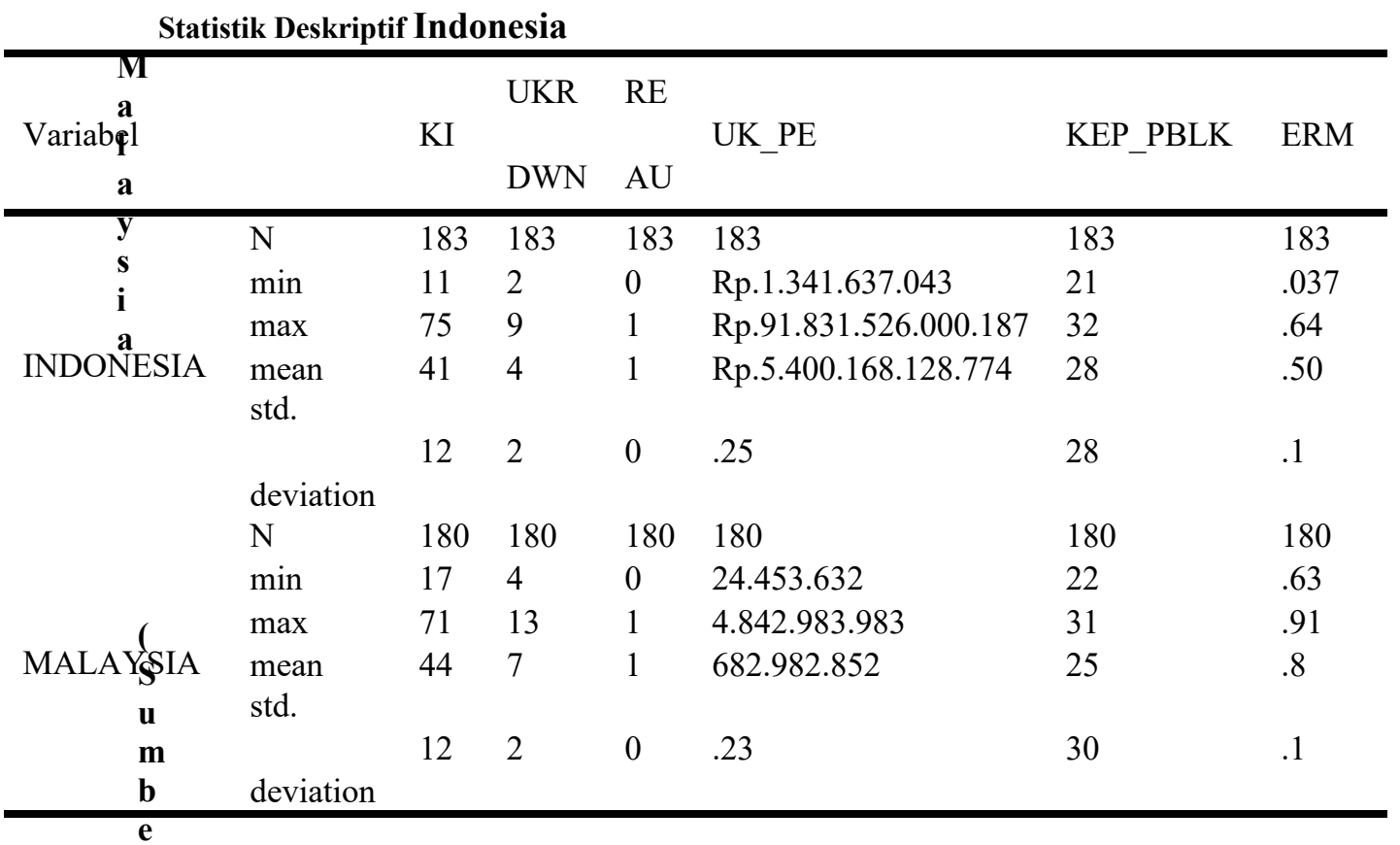

Hasil Output SPSS, 2018

Dari Tabel 2 diprediksi gambaran stastistik deskriptif pada setiap variabel penelitian. Jumlah unit analisis penelitian $(\mathrm{N})$ pada negara Indonesia menunjukkan 183 sampel. Dari tabel menunjukkan bahwa variabel Enterprise Risk Management (ERM) di negara Indonesia memiliki nilai minimum sebesar 0,37 ; nilai maksimum sebesar 0,64 . Artinya, paling rendah perusahaan melakukan pengungkapan ERM sebanyak $37 \%$ dan yang paling tinggi sebesar $64 \%$ dari total item pengungkapan manajemen risiko perusahaan. Nilai rata-rata variabel ERM sebesar 0,5 , dan nilai standar deviasi di Indonesia sebesar 1 .

Jumlah yang berbeda dari unit analisis penelitian $(\mathrm{N})$ pada negara di Malaysia menujukkan terdapat 180 sampel. Dari tabel menunjukkan bahwa variabel Enterprise Risk Management (ERM) di negara Malaysia memiliki nilai minimum sebesar 0,63 ; nilai maksimum sebesar 0,91 . Artinya, paling rendah perusahaan melakukan pengungkapan ERM sebanyak $63 \%$ dan yang paling tinggi sebesar $91 \%$ dari total item pengungkapan manajemen risiko perusahaan. Nilai rata-rata variabel ERM di Malaysia sebesar 8 , dan nilai standar deviasi di Malaysia sebesar 1.

Dapat disimpulkan dari kedua negara yaitu Indonesia dan Malaysia bahwa total pengungkapan manajemen risiko keduanya berbeda. Meskipun kedua negara menggunakan pedoman dalam pengungkapan yang sama. Dilihat kedua negara pengungkapan di Negara Malaysia lebih baik dalam menganalisis luas pengungkapan ERM di perusahaannya. Dari luas pengungkapan ERM di Malaysia dapat dilihat dari nilai maksimum perusahaan sebesar $91 \%$, perusahaan di Malaysia jauh diatas nilai maksimum di Indonesia yaitu sebesar 64\%, itu artinya perusahaan di Malaysia sudah menerapkan manajemen risiko dengan baik di perusahaan yang dikelolanya.

Variabel komisaris independen dikedua negara juga berbeda. Di Indonesia memiliki nilai minimum sebesar 11 orang komisaris independen; maksimum sebesar 75 orang komisaris independen. Dengan nilai rata-rata anggota dewan komisaris independen sebesar 41 orang, dan standar deviasi sebesar 12 orang.

Berbeda dengan variabel komisaris independen di negara Malaysia, yaitu mempunyai nilai minimum 17 anggota dewan komisaris; maksimum sebesar 71 orang dewan komisaris. Dengan nilai rata-rata anggota komisaris independen sebesar 44 orang, dan standar deviasi sebesar 12 orang. Dapat disimpulkan bahwa jumlah anggota komisaris independen di negara Malaysia lebih besar dibandingkan dengan jumlah anggota komisaris 
independen di negara Indonesia.

Variabel jumlah anggota dewan di negara Indonesia memiliki nilai minimum sebesar 2 orang; dan nilai maksimal sebesar 9 orang. Nilai rata-rata jumlah anggota dewan komisaris sebesar 4 orang, dan standar deviasi sebesar 2 orang. Hasil berbeda menunjukkan terdapat perbedaan nilai minimum anggota dewan komisaris sebesar 2 orang; dan nilai maksimum sebesar 13 orang. Nilai rata-rata anggota dewan komisaris di Malaysia sebesar 7 orang, dan standar deviasi sejumlah 2 orang. Dapat disimpulkan bahwa jumlah anggota dewan komisaris di negara Malaysia lebih besar dibandingkan dengan negara Indonesia.

Dari variabel reputasi auditor dapat dilihat kedua negara tersebut terdapat kesamaan nilai minimum sebesar 0; nilai maksimum sebesar 1 . Nilai rata-rata sebesar 1 dan standar deviasi sebesar 0 di negara Indonesia. Di negara Malaysia nilai minimum sebesar 0; nilai maksimum sebesar 1; nilai rata-rata sebesar 1 dan standar deviasi sebesar 0 . Dapat disimpulkan bahwa di kedua negara samasama memiliki nilai minimal, dan maksimal yang sama. Dikarenakan nilai 0 menunjukkan bahwa perusahaan tidak menggunakan jasa auditor Big Four, sedangkan nilai 1 menunjukkan bahwa perusahaan menggunakan jasa auditor Big Four.

Variabel ukuran perusahaan kedua negara tersebut berbeda, dilihat dari nilai minimum di negara Indonesia terdapat $21 \%$ jika dilihat dari total aset yang dimiliki sebesar Rp. 1.341.637.043 yang dimiliki oleh perusahaan PT Mulia Industrindo Tbk, dan nilai aset maksimum sebesar $32 \%$ jika dilihat perusahaan yang memiliki aset tertinggi dicapai oleh PT Indofood Sukses Makmur Tbk dengan aset yang dimiliki sebesar Rp. 91.831.526.000.000. Nilai ratarata total aset di negara Indonesia sebesar Rp. 5.400.168.128.774 dimiliki oleh PT Nusantara Inti Corpora Tbk. Dan nilai standar deviasi di negara Indonesia sebesar $25 \%$.

Dapat dibandingkan dengan nilai aset yang dimiliki perusahaan di Malaysia. Dilihat dari nilai minimum aset yang dimiliki perusahaan Ann Joo Resources Berhad senilai 17\% dengan total aset 24.453.632 (dalam mata uang Ringgit Malaysia) setara dengan Rp. 8.458.654.614 dan nilai maksimum aset yang dimiliki perusahaan Asia Knight Berhad 22\% dengan total aset mencapai 4.842.983.982 (dalam mata uang Ringgit Malaysia) setara dengan Rp.16.752.850.190.532. Nilai rata- rata perusahaan mencapai 682.982.852 (dalam mata uang Ringgit Malaysia) setara dengan $\mathrm{Rp}$. 2.362.574.281.638. Standar deviasi sebesar 23\%. Dapat disimpulkan total aset di Indonesia lebih besar dibandingkan dengan di negara Malaysia.

Variabel kepemilikan publik yang diukur menggunakan presentase perbandingan antara jumlah saham yang dimiliki publik dengan jumlah saham yang beredar. Variabel kepemilikan saham oleh publik memiliki persentase terendah di perusahaan manufaktur di Indonesia sebesar 21\% yang dimiliki oleh PT Keramika Indonesia Assosiasi Tbk, dan persentase kepemilikan tertinggi sebesar $32 \%$ yang dimiliki oleh PT Mulia Industrindo Tbk. Nilai ratarata kepemilikan saham oleh publik di Indonesia sebesar $28 \%$, dan standar deviasi sebesar 1 .

Variabel kepemilikan saham oleh publik di negara Malaysia memiliki persentase terendah 22\% yang dimiliki oleh Nylex Norp Berhad, dan persentase kepemilikan tertinggi sebesar 31\% yang dimiliki oleh Kombay Corp Berhad. Nilai rata-rata kepemilikan saham oleh publik di Indonesia sebesar $25 \%$ dan standar deviasi sebesar 1. Dapat disimpulkan kepemilikan saham oleh publik di kedua negara memiliki perbedaan, negara Indonesia lebih besar dalam kepemilikan saham oleh publik dengan persentase 32\% dibandingkan negara Malaysia.

Analisis Uji Asumsi Klasik

\section{Uji Normalitas}

Tabel 3

Uji Normalitas Data Indonesia

\begin{tabular}{llr}
\hline & & $\begin{array}{c}\text { Unstandardized } \\
\text { Residual }\end{array}$ \\
\hline $\mathrm{N}$ & Mean & 183 \\
Normal Parameters ${ }^{\mathrm{a}, \mathrm{b}}$ & Std. & .0000000 \\
& Deviation & .11878460 \\
& Absolute & .065 \\
Most Extreme Differences Positive & .050 \\
& Negative & -.065 \\
Kolmogorov-Smirnov Z & & .875 \\
Asymp. Sig. (2-tailed) & & .428 \\
\hline
\end{tabular}

(Sumber : Data diolah)

Berdasarkan Tabel 3 didapatkan hasil bahwa nilai Asymp. Sig (2-tailed) data Indonesia sebesar 0,428 > $(0,05)$. Jadi, dapat disimpulkan data pada penelitian dengan menggunakan sample dari perusahaan manufaktur berdistribusi normal. 
Tabel 4

Uji Normalitas Data Malaysia One-Sample Kolmogorov-Smirnov Test

\begin{tabular}{llr}
\hline & & $\begin{array}{r}\text { Unstandardiz } \\
\text { ed Residual }\end{array}$ \\
\hline $\mathrm{N}$ & Mean & 180 \\
Normal Parameters & a,b & .0000000 \\
& Std. & .07431688 \\
& Deviation & \\
& Absolute & .056 \\
Most Extreme DifferencesPositive & .036 \\
& Negative & -.056 \\
\multicolumn{2}{l}{ Kolmogorov-Smirnov Z } & .749 \\
Asymp. Sig. (2-tailed) & & .629 \\
(Sumber : Data diolah) & &
\end{tabular}

Berdasarkan Tabel 4 didapatkan hasil bahwa nilai Asymp. Sig (2-tailed) data Malaysia sebesar 0,629> $(0,05)$. Jadi, dapat disimpulkan data pada penelitian dengan menggunakan sample dari perusahaan manufaktur berdistribusi normal.

\section{Tabel 5}

Uji Autokolerasi data Indonesia

\begin{tabular}{|c|c|c|c|c|c|}
\hline Model & $\mathrm{R}$ & $\begin{array}{c}\mathrm{R} \\
\text { Square }\end{array}$ & $\begin{array}{l}\text { Adjusted } \\
\text { R Square }\end{array}$ & $\begin{array}{l}\text { Std. Error } \\
\text { of the } \\
\text { Estimate }\end{array}$ & $\begin{array}{l}\text { Durbin- } \\
\text { Watson }\end{array}$ \\
\hline 1 & $293^{\mathrm{a}}$ & .086 & .060 & .12045 & 1.832 \\
\hline
\end{tabular}

(Sumber : Data diolah)

Berdasarkan Tabel 5 tampak tidak adanya autokorelasi. Jadi, dapat disimpulkan data pada penelitian dengan sample dari perusahaaan manufaktur di Indonesia tidak terjadi autokolerasi.

Tabel 6

Uji Autokolerasi data Malaysia

\begin{tabular}{cccccc}
\hline Model & $\mathrm{R}$ & $\mathrm{R}$ & Adjusted & Std. Error of Durbin- \\
& \multicolumn{3}{c}{$\begin{array}{l}\text { Square R Square } \\
\text { the Estimate }\end{array}$} & Watson \\
\hline 1 & $.358^{\mathrm{a}}$ & .128 & .103 & .07538 & 1.827 \\
\hline (Sumber : Data diolah) & & &
\end{tabular}

(Sumber : Data diolah)

Berdasarkan Tabel 6 tampak tidak adanya autokorelasi. Jadi, dapat disimpulkan data pada penelitian dengan sample dari perusahaaan manufaktur di Malaysia tidak terjadi autokolerasi.
Tabel 7

Uji Multikolineritas Data Indonesia

\begin{tabular}{lcc}
\hline \multicolumn{1}{c}{ Model } & \multicolumn{2}{c}{ Collinearity Statistics } \\
& Tolerance & VIF \\
\hline (Constant) & & \\
Komensaris & .947 & 1.056 \\
$\begin{array}{l}\text { Independen } \\
\text { Jumlah Anggota }\end{array}$ & .799 & 1.251 \\
$\begin{array}{l}\text { Dewan Komisaris } \\
\text { Reputasi Auditor }\end{array}$ & .898 & 1.113 \\
Ukuran Perusahaan & .860 & 1.162 \\
Struktur Kepemilikan & .981 & 1.020 \\
Publik & & \\
\hline
\end{tabular}

(Sumber : Data diolah)

Berdasarkan Tabel 7 tampak nilai tolerance semua variabel independen diatas variabel komisaris independen 0,947; variabel jumlah anggota dewan komisaris 0,799; variabel reputasi auditor 0,898; variabel ukuran perusahaan 0,860 ; dan variabel struktur kepemilikan publik 0,981. Semua variabel independen diatas $10 \%$ atau diatas 0,01 dan nilai variance inflation factor (VIF) semua variabel indepeden kurang dari 10. Hal ini menunjukkan bahwa data yang digunakan dalam penelitian ini tidak terjadi multikolinearitas.

Tabel 8

Uji Multikolineritas Data Malaysia

\begin{tabular}{lcc}
\hline \multicolumn{1}{c}{ Model } & \multicolumn{2}{c}{ Collinearity Statistics } \\
& Tolerance & VIF \\
\hline (Constant) & & \\
Komensaris Independen & .948 & 1.055 \\
Jumlah Anggota Dewan & .915 & 1.093 \\
Komisaris & & \\
Reputasi Auditor & .942 & 1.061 \\
Ukuran Perusahaan & .903 & 1.107 \\
Struktur Kepemilikan & .960 & 1.042 \\
Publik & & \\
\hline
\end{tabular}

(Sumber : Data diolah)

Berdasarkan Tabel 8 tampak nilai tolerance semua variabel independen diatas variabel komisaris independen 0,948; variabel jumlah anggota dewan komisaris 0,915; variabel reputasi auditor 0,942; variabel ukuran perusahaan 0,903; dan variabel struktur kepemilikan publik 0,960. Semua variabel independen diatas $10 \%$ atau diatas 0,01 dan nilai 
variance inflation factor (VIF) semua variabel indepeden kurang dari 10. Hal ini menunjukkan bahwa data yang digunakan dalam penelitian ini tidak terjadi multikolinearitas.

Tabel 9

Uji Heteroskedastisitas Data Indonesia

\begin{tabular}{lc}
\hline Model & Sig. \\
& \\
\hline (Constant) & .572 \\
Komensaris Independen & .101 \\
Jumlah Anggota Dewan & .381 \\
1 Komisaris & .233 \\
Reputasi Auditor & .544 \\
Ukuran Perusahaan & .899 \\
Struktur Kepemilikan Publik
\end{tabular}

(Sumber : Data diolah)

Berdasarkan Tabel 9 didapatkan hasil bahwa nilai signifikansi dari masing-masing variabel independen pada penelitian ini lebih besar $(0,05)$. Komisaris Independen (KI) sebesar 0,572; Jumlah Anggota Dewan Komisaris (UKR_DWN) sebesar 0,101; Reputasi Auditor (RE_AU) sebesar 0,381; Ukuran Perusahaan (UK_PE) sebesar 0,233; dan Struktur Kepemilikan Publik (KEP_PBLK) sebesar 0,899. Jadi, dapat disimpulkan data pada penelitian ini tidak terjadi heteroskedastisitas.

Tabel 10

Uji Heteroskedastisitas Data Malaysia

\begin{tabular}{ll}
\multicolumn{1}{c}{ Model } & Sig. \\
\hline (Constant) & .211 \\
Komensaris Independen & .149 \\
Jumlah Anggota Dewan & .090 \\
1 Komisaris & \\
Reputasi Auditor & .656 \\
Ukuran Perusahaan & .124 \\
Struktur Kepemilikan & .519 \\
Publik & \\
\hline
\end{tabular}

(Sumber : Data diolah)

Berdasarkan Tabel 10 didapatkan hasil bahwa nilai signifikansi dari masing-masing variabel independen pada penelitian ini lebih besar $(0,05)$. Komisaris Independen (KI) sebesar 0,149; Jumlah Anggota Dewan Komisaris (UKR_DWN) sebesar 0,090; Reputasi Auditor (RE_AU) sebesar 0,656; Ukuran Perusahaan UK PE) sebesar 0,124; dan Struktur Kepemilikan Publik (KEP_PBLK) sebesar 0,519. Jadi, dapat disimpulkan data pada penelitian ini tidak terjadi heteroskedastisitas.

\section{Uji Hipotesis}

Pengujian hipotesis dalam penelitian ini menggunakan analisis regresi berganda. Metode analisis regresi berganda ini digunakan untuk mengetahui pengaruh variabel-variabel independen terhadap variabel dependen dengan menggunakan program SPSS. Pengujian hipotesis ini meliputi tiga bagian yaitu nilai koefisien determinasi (Adjusted $\mathrm{R}_{2}$ ), nilai statistik $\mathrm{F}$ dan nilai statistik $t$.

\section{Uji Koefisien Determinasi (Adjusted $\mathbf{R}_{2}$ )}

\begin{tabular}{|c|c|c|c|}
\hline \multicolumn{4}{|c|}{$\begin{array}{c}\text { Tabel } 11 \\
\text { Uji Koefisien Determinasi } \\
\left(\text { Adjusted } R_{2}\right) \text { Data Indonesia }\end{array}$} \\
\hline Model & R R Square & $\begin{array}{l}\text { Adjusted } \\
\text { R Square }\end{array}$ & $\begin{array}{l}\text { Std. Error of } \\
\text { the Estimate }\end{array}$ \\
\hline 1 & $293^{\mathrm{a}}$ & .060 & .12045 \\
\hline
\end{tabular}

Berdasarkan Tabel 11 didapatkan hasil bahwa besarnya koefisien determinasi (Adjusted $R_{2}$ ) adalah 0,060 atau $6 \%$, hal ini menunjukkan bahwa Luas Pengungkapan Enterprise Risk Management di Indonesia sebesar $6 \%$ yang dapat dijelaskan oleh variabel Komisaris Independen (KI), Jumlah Anggota Dewan Komisaris (UKR DWN), Reputasi Auditor (RE_AU), Ukuran Perusahaan (UK PE) dan Struktur Kepemilikan Publik (KEP_PBLK). Sisanya 94\% (100\%-6\%) dipengaruhi oleh variabel lain diluar model penelitian.
Tabel 12

Uji Koefisien Determinasi (AdjustedR2) Data Malaysia

\begin{tabular}{ccccc}
\hline Model & $\mathrm{R}$ & $\begin{array}{c}\mathrm{R} \\
\text { Square }\end{array}$ & $\begin{array}{c}\text { Adjusted R } \\
\text { Square }\end{array}$ & $\begin{array}{c}\text { Std. Error of } \\
\text { the Estimate }\end{array}$ \\
\hline 1 & $.358^{\mathrm{a}}$ & .128 & .103 & .07538 \\
\hline \multicolumn{5}{c}{ (Sumber : Data diolah) }
\end{tabular}

dasarkan Tabel 12 tampak bahwa besarnya koefisien determinasi (Adjusted $R_{2}$ ) adalah 0,103 atau 10,3\%. Hal ini menunjukkan bahwa Luas Pengungkapan Enterprise Risk Management di Malaysia sebesar $10,3 \%$ yang dapat dijelaskan oleh variabel Komisaris Independen (KI), Jumlah Anggota Dewan Komisaris (UKR_DWN), Reputasi Auditor (RE_AU), Ukuran 
Perusahaan (UK_PE) dan Struktur Kepemilikan Publik (KEP_PBLK). Sisanya 89,7\% (100\%-10,3\%) dipengaruhi oleh variabel lain diluar model penelitian.

\section{Uji signifikan simultan (Uji Nilai F)}

Tabel 13

Uji Signifikan Simultan (Uji F) Data Indonesia

\begin{tabular}{|c|c|c|c|c|c|}
\hline Model & $\begin{array}{l}\text { Sum of } \\
\text { Squares }\end{array}$ & df & $\begin{array}{l}\text { Mean } \\
\text { Square }\end{array}$ & $\mathrm{F}$ & Sig. \\
\hline Regression & .242 & 5 & .048 & 3.336 & $.007^{\mathrm{b}}$ \\
\hline Residual & 2.568 & 177 & .015 & & \\
\hline Total & 2.810 & 182 & & & \\
\hline
\end{tabular}

(Sumber : Data diolah)

Berdasarkan Tabel 13 didapatkan hasil bahwa nilai $\mathrm{F}$ sebesar 3,336 dengan nilai signifikan $\mathrm{F}$ sebesar $0,007<(0,05)$. Jadi, variabel independen (komisaris independen, jumlah anggota dewan komisaris, reputasi auditor, ukuran perusahaan dan struktur kepemilikan publik) berpengaruh simultan atau bersama-sama terhadap variabel dependen (ERM).

\section{Tabel 14}

Uji Signifikan Simultan (Uji Nilai F Data Malaysia

\begin{tabular}{ccccccc}
\hline & Model & $\begin{array}{c}\text { Sum of } \\
\text { Squares }\end{array}$ & df & $\begin{array}{c}\text { Mean } \\
\text { Square }\end{array}$ & F & Sig. \\
\hline & Regression & .145 & 5 & .029 & 5.102 & $.000^{\mathrm{b}}$ \\
1 & Residual & .989 & 174 & .006 & & \\
& Total & 1.134 & 179 & & & \\
\hline
\end{tabular}

(Sumber : Data diolah)

Berdasarkan Tabel 14 tampak bahwa nilai $\mathrm{F}$ sebesar 5.102 dengan nilai signifikan $\mathrm{F}$ sebesar $0,000<$ $(0,05)$. Jadi, variabel independen (komisaris independen, jumlah anggota dewan komisaris, reputasi auditor, ukuran perusahaan dan struktur kepemilikan publik) berpengaruh simultan atau bersama-sama terhadap variabel dependen (ERM).

\section{Uji Nilai t}

\section{Tabel 15}

Uji Nilai t Data Indonesia

Model Unstandardiz Standardize t Sig.
ed d

Coefficients Coefficients
B Std. Beta

Error

\begin{tabular}{lccccc}
\hline (Constant) & .057 & .495 & & .115 & .908 \\
$\begin{array}{l}\text { Komensaris } \\
\text { Independen }\end{array}$ & -.057 & .030 & -.141 & -1.912 & .057 \\
$\begin{array}{l}\text { Jumlah } \\
\text { Anggota }\end{array}$ & .057 & .026 & .172 & 2.143 & .033 \\
$\begin{array}{l}\text { Dewan } \\
\begin{array}{l}\text { Komisaris } \\
\text { Reputasi } \\
\text { Auditor }\end{array}\end{array}$ & -.022 & .024 & -.068 & -.900 & .369 \\
$\begin{array}{l}\text { Ukuran } \\
\begin{array}{l}\text { Perusahaan } \\
\text { Struktur }\end{array}\end{array}$ & -.193 & .147 & -.102 & -1.310 & .192 \\
$\begin{array}{l}\text { Kepemilikan } \\
\text { Publik }\end{array}$ & .149 & .054 & .201 & 2.776 & .006 \\
\hline
\end{tabular}

(Sumber : Data diolah)

Berdasarkan regresi berganda diperoleh persamaan regresi sebagai berikut:

$\mathrm{ERM}=0,057+0.057(\mathrm{KI})+0,057(\mathrm{UKR} \mathrm{DWN})+$ 0,022 (RE_AU) $+0,193\left(\mathrm{UK} \_\mathrm{PE}\right)+0,149$ $\left(\mathrm{KEP} \_\mathrm{PBLK}\right)+e$

Tabel 16

Uji Nilai t Data Malaysia

\begin{tabular}{|c|c|c|c|c|}
\hline Model & \multicolumn{3}{|c|}{$\begin{array}{c}\text { Unstandardized Standardi } \\
\text { Coefficients } \\
\\
\text { Coefficien } \\
\text { ts }\end{array}$} & Sig. \\
\hline (Constant) & -.339 & .369 & & -.919 .359 \\
\hline $\begin{array}{l}\text { Komensaris } \\
\text { Independen }\end{array}$ & .045 & .019 & .173 & 2.382 .018 \\
\hline $\begin{array}{l}\text { Jumlah Anggota } \\
\text { Dewan Komisaris }\end{array}$ & .075 & .026 & .209 & 2.827 .005 \\
\hline Reputasi Auditor & .042 & .015 & .209 & 2.868 .005 \\
\hline $\begin{array}{l}\text { Ukuran } \\
\text { Perusahaan }\end{array}$ & -.087 & .119 & -.054 & -.730 .466 \\
\hline $\begin{array}{l}\text { Struktur } \\
\text { Kepemilikan } \\
\text { Publik }\end{array}$ & -.002 & .010 & -.014 & -.193 .847 \\
\hline
\end{tabular}

(Sumber : Data diolah)

$\begin{aligned} \mathrm{ERM}= & -0,339+0,045(\mathrm{KI})+0,075\left(\mathrm{UKR} \_\mathrm{DWN}\right)+0,042 \\ & \left(\mathrm{RE} \_\mathrm{AU}\right)+0,087\left(\mathrm{UK} \_\mathrm{PE}\right)+0,002(\mathrm{KEP} \text { _PBLK }) \\ & +\mathrm{e}\end{aligned}$

Hasil pengujian terhadap hipotesis- hipotesis yang diteliti:

\section{a. Pengaruh Komisaris Independen terhadap} Enterprise Risk Management.

Tabel 15 menunjukkan data dari Indonesia 
bahwa komisaris independen memiliki nilai koefisien regresi sebesar $-0,057$ dengan nilai signifikansi sebesar $0,057>$ alpha $(0,05)$. Artinya variabel komisaris independen tidak berpengaruh signifikan terhadap luas pengungkapan Enterprise risk management. Sehingga dapat disimpulkan bahwa hipotesis satu $\left(\mathrm{H}_{\mathrm{a}}\right)$ ditolak.

Hal yang mendasari hipotesis ini ditolak mungkin disebabkan karena kualitas fungsi pengawasan bukan ditentukan oleh tingkat independensi tetapi lebih ditentukan oleh kualitas dan latar belakang pendidikan anggota dewan komisaris. Pengangkatan komisaris independen dilakukan untuk memenuhi regulasi semata, tidak untuk melaksanakan good corporate governance (Meisaroh dan Lucyanda, 2011).

Hasil penelitian ini konsisten dengan penelitian dan (Meizaroh \& Lucyanda, 2011) yang menunjukkan kehadiran komisaris independen tidak berpengaruh pada tingkat adopsi ERM.

Jika dilihat dari data yang terdapat di negara Malaysia bahwa berdasarkan Tabel 16 menunjukkan komisaris independen memiliki nilai koefisien regresi sebesar 0,045 dengan nilai signifikansi sebesar $0,018>$ alpha $(0,05)$. Artinya variabel komisaris independen tidak berpengaruh signifikan terhadap luas pengungkapan Enterprise risk management. Sehingga dapat disimpulkan bahwa hipotesis satu $\left(\mathrm{H}_{\mathrm{b}}\right)$ diterima.

Hasil dan interpretasi ini didukung dengan argumentasi bahwa fungsi pengawasan dewan komisaris yang baik tidak hanya berdasarkan pada kuantitas dari komisaris independen dalam suatu perusahaan, namun lebih ditentukan oleh pengalaman, kompetensi dan komitmen dalam menerapkan dan mengungkapkan ERM, serta spesialisasi yang sesuai dengan bidang perusahaan sehingga menunjang dewan komisaris untuk lebih memahami profil risiko sesuai dengan bidang perusahaan (Utami, 2015).

Faktor lain yang mendasari hipotesis ini diterima mungkin dilihat dari latar belakang pendidikan masing-masing angggota komisaris independen tersebut. Latar belakang pendidikan yang memumpuni membuat pemikiran dan strategi yang baik untuk mengembangkan pola pemikiran antar individu satu dengan yang lainnya. Selain faktor pendidikan tujuan dewan komisaris independen yaitu untuk mendorong suatu keadaan yang lebih baik dan menaruh keseimbangan diantara para kepentingan perusahaan dengan kepentingan stakeholder. Dengan adanya kesinambungan antara komisaris independen dengan stakeholder maka kerjasama keduannya akan menghasilkan hubungan baik antar pihak internal dan eksternal perusahaan.

\section{b. Pengaruh Jumlah Anggota Dewan Komisaris} terhadap Enterprise Risk Management.

Berdasarkan Tabel 15 yang menjelaskan data dari Indonesia tampak bahwa jumlah anggota dewan komisaris memiliki nilai koefisien regresi sebesar 0,057 dengan nilai signifikansi sebesar $0,033>$ alpha $(0,05)$. Variabel jumlah anggota dewan komisaris di Indonesia diterima.

Berdasarkan Tabel 16 yang menjelaskan data dari Malaysia tampak bahwa nilai koefisien regresi sebesar 0,075 dengan nilai signifikansi sebesar 0,005 $>$ alpha $(0,05)$ Artinya variabel jumlah anggota dewan komisaris di negara Indonesia dan Malaysia diterima.

Kedua negara tersebut sama sama mempunyai berpengaruh positif dan signifikan terhadap luas pengungkapan enterprise risk management. Sehingga dapat disimpulkan bahwa jumlah anggota dewan komisaris berpengaruh terhadap luas pengungkapan enterprise risk management.

Semakin besar proporsi jumlah anggota dewan komisaris, maka akan meningkatkan kapasitas monitoring dan pemberian informasi serta kualitas pengungkapan manajemen risiko, karena besarnya jumlah anggota dewan komisaris memungkinkan perusahaan tidak didominasi oleh pihak manajemen dalam menjalankan perannya secara lebih efektif Hasil penelitian ini konsisten dengan penelitian (Ardiansyah \& Adnan, 2014)

\section{c. Pengaruh reputasi auditor terhadap Enterprise Risk Management.}

Berdasarkan Tabel 15 tampak reputasi auditor memiliki nilai koefisien regresi sebesar -0,022 dengan nilai signifikansi sebesar $0,369>$ alpha $(0,05)$. Artinya variabel reputasi auditor memiliki pengaruh positif dan signifikan terhadap luas pengungkapan enterprise risk management. Sehingga dapat disimpulkan bahwa hipotesis tiga $\left(\mathrm{H} 3_{\mathrm{b}}\right)$ ditolak.

Berdasarkan Tabel 16 menunjukkan reputasi auditor memiliki nilai koefisien regresi sebesar 0,042 dengan nilai signifikansi sebesar $0,005>$ alpha $(0,05)$. Artinya variabel reputasi auditor memiliki pengaruh positif dan signifikan terhadap luas pengungkapan enterprise risk management. Sehingga dapat disimpulkan bahwa hipotesis tiga $\left(\mathrm{H} 3_{b}\right)$ diterima.

Berdasarkan hasil yang di dapat terdapat 
perbedaan yang mendasari bahwa reputasi auditor yang bergabung dalam Big Four belum bisa dikatakan memiliki dampak besar dalam pengungkapan manajemen resiko di masing-masing perusahaan, baik perusahaan manufaktur di Indonesia dan juga Malaysia. Bisa dilihat dalam annual report disetiap perusahaan tidak semua perushaan disetiap tahunnya menggunakan jasa auditor yang bergabung dalam Big Four.

\section{d. Pengaruh ukuran perusahaan terhadap Enterprise Risk Management.}

Berdasarkan Tabel 15 yang menjelaskan data dari Indonesia tampak bahwa ukuran peruahaan memiliki nilai koefisien regresi sebesar $-0,193$ dengan nilai signifikansi sebesar $0,192>$ alpha $(0,05)$. Berdasarkan Tabel 16 yang menjelaskan data dari Malaysia tampak bahwa nilai koefisien regresi sebesar -0,087 dengan nilai signifikansi sebesar $0,466>$ alpha $(0,05)$ artinya variabel ukuran perusahaan di negara Indonesia dan Malaysia pengaruh positif dan signifikan terhadap luas pengungkapan enterprise risk management.

Semakin tinggi total aset yang dimiliki suatu perusahaan baik di perusahaan Indonesia dan Malaysia maka semakin tinggi pula pengungkapan risiko manajemennya.Ukuran perusahaan akan mampu mengendalikan dan mengontrol pihak manajemen, sehingga perusahaan dengan skala besar umumnya akan cenderung mengadopsi praktik corporate governance dengan lebih baik jika dibandingkan dengan perusahaan kecil.

Hal tersebut dikarenakan semakin besar suatu perusahaan maka semakin tinggi tingkat risiko yang dihadapi seperti risiko keuangan, risiko operasional, risiko reputasi, peraturan dan risiko informasi. Akibatnya pengungkapan manajemen risiko akan lebih tinggi. Perusahaan yang besar akan cenderung melakukan pengungkapan untuk menjaga reputasinya agar tetap mendapatkan kepercayaan dari pihak stakeholder.

\section{e. Pengaruh struktur kepemilikan publik terhadap Enterprise Risk Management.}

Berdasarkan Tabel 15 tampak struktur kepemilikan publik memiliki nilai koefisien sebesar 0,149 dengan nilai signifikansi sebesar 0,006 < alpha $(0,05)$. Artinya variabel struktur kepemilikan publik memiliki pengaruh positif dan signifikan terhadap luas pengungkapan enterprise risk management. Sehingga dapat disimpulkan bahwa hipotesis lima (H5a) diterima.

Berdasarkan Tabel 16 menunjukkan struktur kepemilikan publik memiliki nilai koefisien sebesar 0,002 dengan nilai signifikansi sebesar $0,847>$ alpha $(0,05)$. Artinya variabel struktur kepemilikan publik memiliki pengaruh positif dan signifikan terhadap luas pengungkapan enterprise risk management. Sehingga dapat disimpulkan bahwa hipotesis lima $\left(\mathrm{H} 5_{\mathrm{b}}\right)$ ditolak.

Kepemilikan perusahaan oleh pihak luar memiliki kekuatan yang besar dalam memengaruhi perusahaan melalui media massa berupa kritikan atau komentar yang semuanya dianggap sebagai suara masyarakat. Adanya konsentrasi kepemilikan publik menimbulkan pengaruh pihak luar sehingga mengubah pengelolaan perusahaan yang pada awalnya berjalan sesuai keinginan manajemen menjadi memiliki keterbatasan. Semakin besar porsi saham yang dimiliki publik, maka akan semakin besar tekanan yang diterima perusahaan untuk menyediakan informasi lebih banyak dalam laporan tahunannya yang di dalamnya terdapat pula pengungkapan tentang manajemen risiko.

Hasil penelitian ini sejalan dengan yang dilakukan oleh Abdullah dan Ardiansyah (2017) yang menyatakan bahwa kepemilikan saham oleh publik tidak berpengaruh terhadap pengungkapan melalui ERM.

Alasan mendasar dari tertolaknya hipotesis dalam penelitian ini dimungkinkan karena kepemilikan saham yang kepemilikannya dibawah 5\% dan sifatnya adalah untuk diperjualbelikan dan bukan untuk pengendalian manajemen. Berdasarkan dari sifat kepemilikan saham yang hanya untuk diperjualbelikan dan bukan untuk digunakan sebagai pengendalian manajemen, kemungkinan secara keseluruhan informasi perusahaan kurang begitu diperhatikan oleh pemegang saham dengan proporsi dibawah 5\%. Hal ini mungkin menjadi pertimbangan manajemen perusahaan dalam melakukan penyebarluasan informasi mengenai laporan keuangan dalam website pribadi perusahaan.

\section{SIMPULAN}

Penelitian ini menggunakan data laporan tahunan perusahaan manufaktur yang terdaftar pada Bursa Efek Indonesia (BEI) dan Bursa Malaysia (BM) periode pengamatan tahun 2015-2017. Variabel dependen yang digunakan ialah Enterprise Risk 
Management dan variabel independen ialah komisaris independen, jumlah anggota dewan komisaris, reputasi auditor, ukuran perusahaan, dan struktur kepemilikan publik. Analisis yang digunakan dalam penelitian ini adalah analisis regresi berganda dengan menggunakan Statistical Package for Social Science (SPSS) versi 15.0.

Berdasarkan hasil uji hipotesis dan pembahasan, maka diambil kesimpulan sebagai berikut:

1. Komisaris independen berpengaruh negatif terhadap Enterprise Risk Management di perusahaan manufaktur di Indonesia, dan berpengaruh positif terhadap Enterprise Risk Management di perusahaan manufaktur di Malaysia.

2. Jumlah anggota dewan komisaris berpengaruh positif terhadap Enterprise Risk Management baik di Indonesia maupun di Malaysia

3. Reputasi auditor berpengaruh negatif terhadap Enterprise Risk Management di Indonesia, dan berpengaruh positif terhadap Enterprise Risk Management di Malaysia.

4. Ukuran perusahaan berpengaruh negatif terhadap Enterprise Risk Management baik di Indonesia maupun di Malaysia.

Struktur kepemilikan publik berpengaruh positif terhadap Enterprise Risk Management di Indonesia, dan berpengaruh negatif terhadap Enterprise Risk Management di Malaysia

\section{DAFTAR PUSTAKA}

Abdullah, M. D. F., \& Ardiansyah, M. noor. (2017). "The Effect of Company Size, Company Age, Public Ownership and Audit Quality on Internet Financial Reporting." Sriwijaya International Journal of Dynamic Economics and Business, 1(2), 153-165.

Agista, G. G., Putu, N., \& Harta, S. (2017). Pengaruh Corporate Governance Structure dan Konsentrasi Kepemilikan Pada Pengungkapan Enterprise Risk Management. E-Jurnal Akuntansi Universitas Udayana, Vol 20 No, 89-105.

Ardiansyah, L. O. M., \& Adnan, M. A. (2014). Faktor-Faktor Yang Mempengaruhi Luas Pengungkapan Enterprise Risk Management. Jurnal Ekonomi, Manajemen, Dan Akutansi, Vol 23 No, 89-105.

Dzakawali, M. G., Nazar, M. R., \& Yudowati, S. P. (2017). Risk Management (Studi Kasus Pada Perusahaan Sektor Perbankan Yang Terdaftar Di Bursa Efek Indonesia Pada Tahun 2013 - 2015). Vol 4 No 3, 2597-2604.

Fathimiyah, V., Zulfikar, R., \& Fitriyani, F. (2012). Pengaruh Struktur Kepemilikan Terhadap Risk Management Disclosure (Studi Survei Industri Perbankan Yang
Listing Di Bursa Efek Indonesia Tahun 2008-2010).

Proceeding Simposium Nasional Akuntansi XV

Banjarmasin, 1-26.

Firdaus, Haris, A. (2014). Pengaruh Leverage, Profitabilitas dan Struktur Kepemilikan Publik Terhadap Risk Management Disclosure (Studi Pada Perbankan yang Terdaftar di BEI Tahun 2011).

Halim, E. H., Mustika, G., Sari, R. N., Anugerah, R., \& MohdSanusi, Z. (2017). Corporate Governance Practices and Financial Performance: The Mediating Effect of Risk Management Committee at Manufacturing Firms. Journal of International Studies, Vol 10 No, 272-289.

Handayani, B. D., \& Yanto, H. (2013). Determinan Pengungkapan Enterprise Risk Managemen. Jurnal Keuangan Dan Perbankan, Vol 17 No, 1-17.

Kanhai, C., \& L, G. (2014). Factors Influencing The Adoption Of Enterprise Risk Management (ERM) Practices By Banks in Zimbabwe. International Journal of Business and Commerce, Vol 3 No 6, 1-17.

Meizaroh, \& Lucyanda, J. (2011). Pengaruh Corporate Governance dan Konsetrasi Kepemilikan pada Pengungkapan Enterprise Risk Management. Proceeding Simposium Nasional Akuntansi XIV Aceh, 1-25.

Prayoga, E. B., \& Almilia, L. S. (2013). Pengaruh Struktur Kepemilikan dan Ukuran Perusahaan terhadap Pengungkapan Manajemen Risiko. Jurnal Akuntansi Dan Keuangan, Vol 4 No 1, 1-9.

Utami, I. C. (2015). Pengaruh Dewan Komisaris, Komite Audit, Internal Audit, Komite Manajemen Resiko, dan Ukuran Perusahaan terhadap Pengungkapan Enterprise Risk Management. Journal of Applied Microbiology.

Wulandari, R. F. (2018). "Pengaruh Mekanisme Corporate Governance dan Struktur Kepemilikan Publik Terhadap Luas Pengungkapan Enterprise Risk Management." Jurnal Manajemen Teori Dan Terapan, 1-16. https://doi.org/10.1016/j.ijheatmasstransfer.2017.09.124 